\title{
Sorption of Perfluorinated Compounds onto different types of sewage sludge and assessment of its importance during wastewater treatment
}

\author{
Arvaniti, Olga S.; Andersen, Henrik Rasmus; Thomaidis, Nikolaos S.; Stasinakis, Athanasios S.
}

Published in:

Chemosphere

Publication date:

2014

Link back to DTU Orbit

Citation (APA):

Arvaniti, O. S., Andersen, H. R., Thomaidis, N. S., \& Stasinakis, A. S. (2014). Sorption of Perfluorinated Compounds onto different types of sewage sludge and assessment of its importance during wastewater treatment. Chemosphere, 111, 405-411.

\section{General rights}

Copyright and moral rights for the publications made accessible in the public portal are retained by the authors and/or other copyright owners and it is a condition of accessing publications that users recognise and abide by the legal requirements associated with these rights.

- Users may download and print one copy of any publication from the public portal for the purpose of private study or research.

- You may not further distribute the material or use it for any profit-making activity or commercial gain

- You may freely distribute the URL identifying the publication in the public portal 


\title{
Sorption of Perfluorinated Compounds onto different types of sewage sludge and assessment of its importance during wastewater treatment
}

\author{
Olga S. Arvaniti ${ }^{1}$, Henrik R. Andersen ${ }^{2}$, Nikolaos S. Thomaidis ${ }^{3}$, Athanasios S. Stasinakis ${ }^{1 *}$
}

${ }^{1}$ Department of Environment, University of the Aegean, Mytilene, Greece

${ }^{2}$ Department of Environmental Engineering, Technical University of Denmark, Miljoevej, B 113, 2800 Kgs. Lyngby, Denmark

${ }^{3}$ Department of Chemistry, National and Kapodistrian University of Athens, Panepistimiopolis Zografou, 15771 Athens, Greece

*Corresponding author. Tel.: +30 22510 36257; fax: +30 22510 36206. E-mail address: astas@env.aegean.gr

\section{HIGHLIGHTS}

* $\mathrm{K}_{\mathrm{d}}$ of 4 PFCs were measured for primary, secondary and digested sludge

* Lower $\mathrm{pH}$ and higher $\left[\mathrm{Ca}^{2+}\right]$ increased PFCs sorption to sludge significantly

* PFCs with $\mathrm{K}_{\mathrm{d}} \geq 2500 \mathrm{~L} \mathrm{Kg}^{-1}$ can be removed more than $60 \%$ via primary and excess sludge

* In anaerobic digesters, $>76 \%$ of PFCs are predicted to be sorbed to sludge

\section{Graphical Abstract}

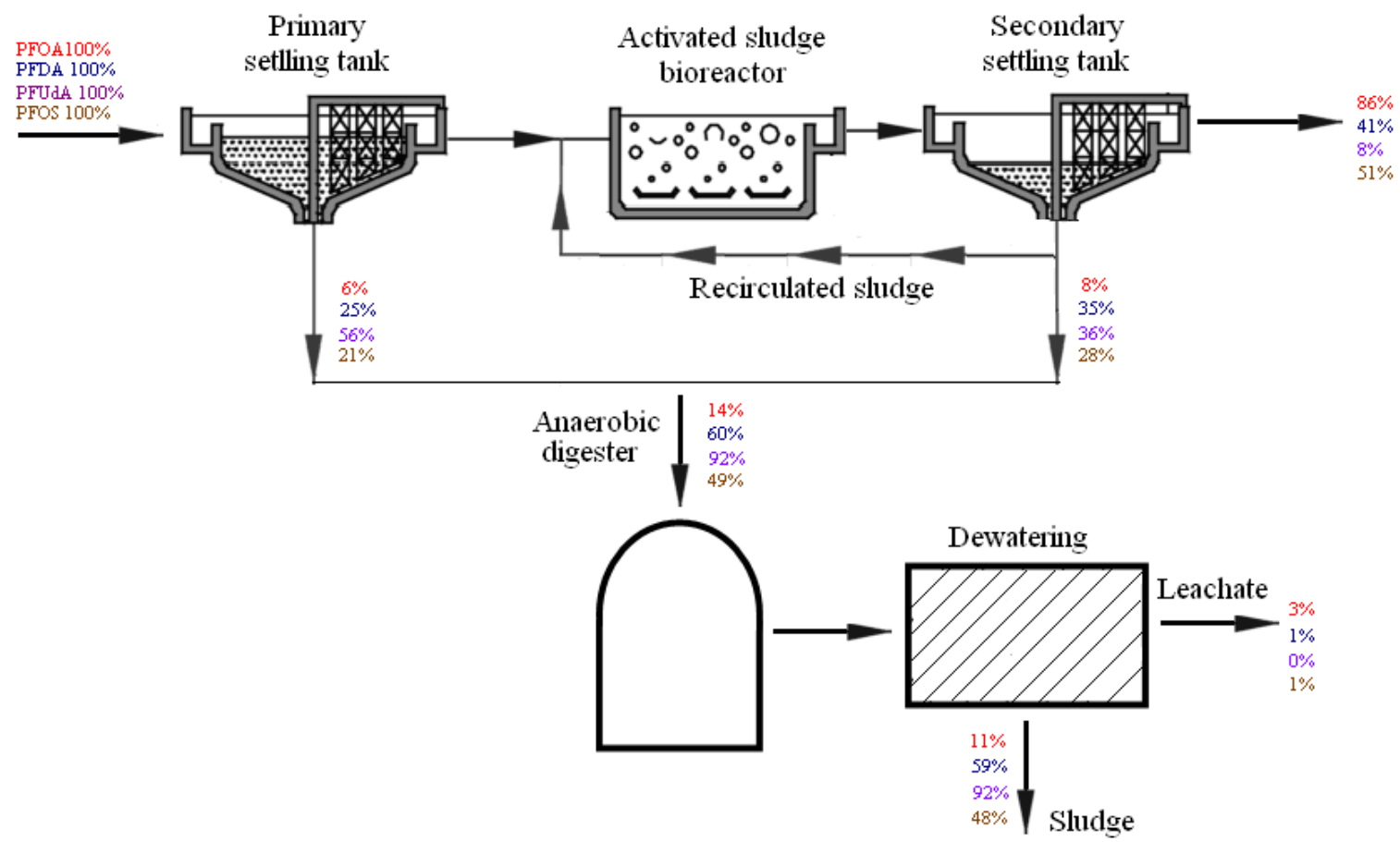




\section{ABSTRACT}

The distribution coefficient $\left(\mathrm{K}_{\mathrm{d}}\right)$ and the organic carbon distribution coefficient $\left(\mathrm{K}_{\mathrm{OC}}\right)$ were determined for four Perfluorinated Compounds (PFCs) to three different types of sludge taken from a conventional Sewage Treatment Plant (STP). Batch experiments were performed in six different environmental relevant concentrations $\left(200 \mathrm{ng} \mathrm{L}^{-1}\right.$ to $\left.5 \mu \mathrm{g} \mathrm{L}^{-1}\right)$ containing $1 \mathrm{~g} \mathrm{~L}^{-1}$ sludge. $\mathrm{K}_{\mathrm{d}}$ values ranged from 330 to 6015,329 to 17432 and 162 to $11770 \mathrm{~L} \mathrm{Kg}^{-1}$ for primary, secondary and digested sludge, respectively.

The effects of solution's $\mathrm{pH}$, ionic strength and cation types on PFCs sorption were also evaluated. Sorption capacities of PFCs significantly decreased with increased $\mathrm{pH}$ values from 6 to 8 . Furthermore, the divalent cation $\left(\mathrm{Ca}^{2+}\right)$ enhanced PFCs sorption to a higher degree in comparison with the monovalent cation $\left(\mathrm{Na}^{+}\right)$at the same ionic strength.

The obtained $\mathrm{K}_{\mathrm{d}}$ values were applied to estimate the sorbed fractions of each PFC in different stages of a typical STP and to calculate their removal through treated wastewater and sludge. In primary settling tank, the predicted sorbed fractions ranged from 3\% for Perfluorooctanoic acid (PFOA) to $55 \%$ for Perfluoroundecanoic acid (PFUdA), while in activated sludge tank and anaerobic digester sorption was more than $50 \%$ for all target compounds. Almost $86 \%$ of initial PFOA load is expected to be detected in treated wastewater; while Perfluorodecanoic acid (PFDA), PFUdA and Perfluorooctanesulfonate (PFOS) can be significantly removed ( $>49 \%)$ via sorption to primary and excess secondary sludge. In anaerobic digester, the major part $(>76 \%)$ of target PFCs is expected to be sorbed to sludge, while almost 3\% of initial PFOA load will be detected in sludge leachates.

Keywords: Sludge; Perfluorochemicals; Distribution Coefficient $\left(\mathrm{K}_{\mathrm{d}}\right)$; Sorption; Fate; Sewage Treatment 


\section{Introduction}

Perfluorinated Compounds (PFCs) are a new class of Persistent Organic Pollutants. They consist of a hydrophobic perfluorinated carbon tail and a hydrophilic ionic head. Due to the unique structure of fluoride-carbon bond, they present significant thermal and chemical stability. As a result, they have a wide variety of applications in firefighting foams, food packing, waterproof breathable fabrics and Teflon production [Ahrens, 2011].

During the last years, PFCs have attracted scientific interest, due to their widespread occurrence in the environment as well as their environmental persistence, bioaccumulation potential and potential toxicity [Ahrens, 2011]. PFCs have been detected in several environmental samples, such as wastewater, surface water and groundwater at concentrations up to some hundreds ng L ${ }^{-1}$ [Müller et al., 2011, Arvaniti et al., 2012, Stasinakis et al., 2013, Eschauzier et al., 2013], as well as in sewage sludge, soil and sediment in the range of some $\mathrm{pg} \mathrm{g}^{-1}$ to few $\mathrm{ng} \mathrm{g}^{-1}$ [Arvaniti et al., 2012, Pico at al., 2012, Wang et al., 2013].

Due to PFCs' recalcitrance, no degradation is expected during conventional wastewater treatment, while sorption seems to be an important mechanism governing their removal [Sinclair and Kannan, 2006, Arvaniti et al., 2012]. However, so far, there are limited papers investigating in depth PFCs' sorption to different types of sewage sludge. Specifically, Zhou et al. (2010) reported sludge-water distribution coefficients $\left(\mathrm{K}_{\mathrm{d}}\right)$ values for Perfluorooctane Sulfonate (PFOS) and Perfluorooctanoic Acid (PFOA) on activated sludge; whereas Ochoa-Herrena and Sierra-Alvarez (2008) reported $\mathrm{K}_{\mathrm{d}}$ values only for PFOS in different types of anaerobic sludge. The aforementioned studies were performed in batch experiments using very high concentrations of the target compounds, about 100 to 10.000 fold higher than sewage and environmental relevant concentrations. Additionally to the above, full-scale Sewage Treatment Plants (STPs) $K_{d}$ values have been calculated for some PFCs to primary and secondary sludge by Yu et al. (2009) and Arvaniti et al. (2012). Finally, in a very recent sorption study by Zhang et al. (2013), the sorption of several PFCs onto secondary sludge was described using Freundlich isotherms. Experiments were performed using activated sludge sterilized by $\mathrm{NaN}_{3}$, while concentrations of the target compounds in the range of $5 \mu \mathrm{g} \mathrm{L}^{-1}$ to $500 \mu \mathrm{g}$ $\mathrm{L}^{-1}$ were used for sorption experiments. However, according to recent publications, $\mathrm{NaN}_{3}$ affects sorption properties and structure of activated sludge [Pierre et al., 2013]; whereas the elaboration of sorption experiments at concentrations much higher than the environmental relevant can affect the validity of the results [Wick et al., 2011]. On the other hand, to our knowledge, excepting from one publication that reports organic carbon distribution coefficient $\left(\mathrm{K}_{\mathrm{OC}}\right)$ values for PFOA and PFOS to activated sludge [Yu et al., 2009], no experimental $\mathrm{K}_{\mathrm{OC}}$ values exist for other PFCs. Additionally, there is lack of data for the distribution of these compounds between water and solid phase in different stages of a STP and for the role of different sludge outflows on their removal.

The main objectives of this study were to determine $K_{d}$ and $K_{O C}$ values for four PFCs (PFOA, PFOS, Perfluorodecanoic acid, PFDA and Perfluoroundecanoic acid, PFUdA) to primary, secondary and digested sludge at environmentally relevant concentrations $\left(200 \mathrm{ng} \mathrm{L}^{-1}\right.$ and $\left.5 \mu \mathrm{g} \mathrm{L}^{-1}\right)$ and apply the obtained $\mathrm{K}_{d}$ values to evaluate the fate of PFCs in a typical STP. The fraction of PFCs sorbed onto primary and secondary settling tank as well as in anaerobic digester was estimated for each target compound for SS concentrations commonly found in STPs. Furthermore, the removal of PFCs via removed sludge and their discharge to the environment were assessed. Last, the effects of $\mathrm{pH}$, ionic strength and cations on PFCs sorption to secondary sludge were investigated.

\section{Materials and methods}

\subsection{Chemicals and reagents}

PFOS (purity $>98 \%$ ) was obtained from Sigma (Seelze, Germany). All other standards were supplied from Alfa Aesar (Karlsruhe, Germany) with purity $\geq 95 \%$. Two isotopically labelled 
standards $(\geq 98 \%)$ were purchased from Wellington Laboratories (Guelph, Ontario, Canada) and used as internal standards. Properties of all analytical standards are summarized in Table S1. Methanol and acetonitrile HPLC-MS grade were obtained from Merck (Frankfurt, Germany); whereas ammonium formate was supplied by Fluka (Buchs, Switzerland). Distilled water was provided by a MilliQ system (Milli-Q Gradient A10, Molsheim, France). OASIS HLB (200 mg, 6 $\mathrm{mL}$ ) solid-phase extraction (SPE) cartridges were purchased from Waters (Milford, MA, USA). All standards stock solutions were prepared in methanol and stored in dark at $4{ }^{\circ} \mathrm{C}$.

\subsection{Characteristics and sampling of sewage sludge}

All types of sludge (primary, secondary and anaerobically digested) were collected from a STP serving 3,700,000 inhabitants (Athens, Greece). The wastewater treatment process involves primary sedimentation, activated sludge process with biological nitrogen (nitrification, denitrification) and biological phosphorus removal, and secondary sedimentation. In the activated sludge bioreactors, hydraulic retention time was $9 \mathrm{~h}$, while solids residence time (SRT) was 7 days. Sludge treatment included thickening, mesophilic anaerobic digestion, dewatering and thermal drying. Anaerobic digesters are operated at a SRT of $20 \mathrm{~d}$. The concentration of total suspended solids (TSS) in activated sludge tanks was $4.2 \mathrm{~g} \mathrm{~L}^{-1}$, while TSS concentrations in primary, secondary and digested sludge were $35.5,8.0$ and $32.3 \mathrm{~g} \mathrm{~L}^{-1}$, respectively. The characteristics of different sludge types used in this study are presented in Table S2.

Samples were collected in high-density polyethylene bottles and immediately transported to the laboratory. Sludge preparation for sorption experiments was based on previous studies [Andersen et al., 2005, Hörsing et al., 2011]. In brief, each type of sludge was washed three times using tap water, centrifuged to remove water soluble constituents and frozen at $-18{ }^{\circ} \mathrm{C}$ for $24 \mathrm{~h}$. Afterwards, sludge was gently freeze dried to preserve its structure, sterilized by heating at $103{ }^{\circ} \mathrm{C}$ for minimum $3 \mathrm{~h}$ and stored at $4{ }^{\circ} \mathrm{C}$.

\subsection{Sorption experiments}

Batch kinetic experiments were performed to investigate the time at which equilibrium between PFCs concentrations in the water and secondary sludge was established. $1 \mathrm{~g} \mathrm{~L}^{-1}$ secondary sludge suspensions were prepared in 6 polypropylene flasks by re-suspending weighted amounts of sludge in $10 \mathrm{~mL}$ tap water. Small amounts of target compounds $(50 \mu \mathrm{L})$ were added in each flask to give a final concentration of $5 \mu \mathrm{g} \mathrm{L}^{-1}$ for each PFC. Flasks were wrapped in aluminum foil to prevent PFCs' photodegradation and shaked at $125 \mathrm{rpm}$. Flasks were removed at selected time intervals $(0$, $4,8,12,24,48 \mathrm{~h}$ ) and PFCs were determined in the dissolved and particulate phase. Based on these results, the total concentration of each PFC was calculated through a mass balance in different flasks to check sludge inactivation.

To determine $K_{d}$ values of PFCs for primary, secondary and digested sludge, batch experiments were conducted for a range of initial concentrations. Each target compound was added at different concentrations $\left(0.2,0.4,0.8,1.5,3\right.$ and $\left.5 \mu \mathrm{g} \mathrm{L}^{-1}\right)$ to $1 \mathrm{~g} \mathrm{~L}^{-1}$ sludge and $40 \mathrm{~mL}$ tap water. Flasks were put on a shaker, while samples were taken at the chosen equilibrium time $(15 \mathrm{~h})$ and PFCs concentrations were determined in the dissolved phase.

To investigate the effect of solution's $\mathrm{pH}$ on PFCs sorption to secondary sludge, batch experiments were performed at three $\mathrm{pH}$ values $(6.0 \pm 0.1,7.0 \pm 0.1,8.0 \pm 0.1)$ at a concentration level of $1.5 \mu \mathrm{g} \mathrm{L}^{-1}$ for each analyte. Additional experiments were performed using secondary sludge to examine the influence of ionic strength and cation types on PFCs sorption. The concentrations of $\mathrm{Ca}^{2+}$ and $\mathrm{Na}^{+}$ranged from 1 to $100 \mathrm{mM}$ and PFCs concentrations were equal to $1.5 \mu \mathrm{g} \mathrm{L}^{-1}$.

In each of the experiments described, control runs without sludge were performed to estimate the impact of other processes (e.g., sorption onto flask walls) on PFCs removal. Furthermore, unspiked samples, taken from Athens STP, were analyzed to quantify background concentration of each analyte in sludge. All experiments were performed at $25.0 \pm 1.0{ }^{\circ} \mathrm{C}$ and at stable $\mathrm{pH}$ conditions. 
Excepting for kinetic experiment, all experiments were conducted in triplicates. Further details on the experimental design are described in Table S3.

\subsection{Analytical methods}

For the investigation of PFCs sorption on different types of sludge, samples from sorption batch experiments were filtered through pre-ashed glass-fiber filters (GF/F, Whatman, UK) and filtrates were stored in the dark at $4{ }^{\circ} \mathrm{C}$ until extraction. For the determination of PFCs in the particulate phase (equilibrium time experiment), filters were oven dried in $60{ }^{\circ} \mathrm{C}$ until constant weight and stored at $-18{ }^{\circ} \mathrm{C}$ until analysis. Prior to extraction procedure, samples were spiked with $0.5 \mu \mathrm{g} \mathrm{L}^{-1}$ of each internal standard. Detailed information for the extraction of PFCs in wastewater and sludge is reported in Arvaniti et al. (2014). In brief, PFCs in water samples were extracted using SPE. Extraction of sludge samples was accomplished using $7.5 \mathrm{~mL}$ of $1 \% \mathrm{v} / \mathrm{v}$ acetic acid and $1.5 \mathrm{~mL}$ of $\mathrm{MeOH}$. This procedure was performed three successive times for each sample, followed by SPE cleanup of the combined extract. Analysis was performed using an Agilent HPLC-MS system. The optimized conditions for PFCs analysis are presented in Table S4. The accuracy of the methods was determined by comparing the response from analysis of spiked samples (sludge samples fortified prior to extraction) with matrix matched samples (sludge samples fortified prior to HPLC-MS examination) for the same fortification level. The recoveries ranged for water and solid samples from $72.3 \%$ to $112 \%$ and from $54.6 \%$ to $93.2 \%$, respectively (Table S5). Precision data of the analytical procedure shown satisfactory repeatability and reproducibility for both wastewater and sewage sludge samples (RSD $<16 \%$ ), as presented in Table S6. Limits of quantification (LOQs) of PFCs ranged from 45.9 to $94.8 \mathrm{ng} \mathrm{L}^{-1}$ for liquid samples and from 25.6 to $75.0 \mathrm{ng} \mathrm{g}^{-1}$ for solid samples (Table S5). Teflon bottles, Teflon-lined caps and any suspect fluoropolymer materials were avoided throughout the analysis, in order to avoid contamination of the samples. During each batch analysis, procedure blanks were also checked to serve as quality control, indicating that no contamination occurred during sampling and analysis.

\subsection{Calculations}

The obtained data from sorption batch experiments were described by the sludge water distribution coefficient, $\mathrm{K}_{\mathrm{d}}\left(\mathrm{L} \mathrm{Kg}^{-1}\right)$, according to Eq. (2.1),

$$
K_{d}=\frac{C_{S}}{C_{W}}
$$

Where, $\mathrm{C}_{\mathrm{s}}$ and $\mathrm{C}_{\mathrm{w}}$ are the equilibrium concentration of each PFC in sludge (ng $\mathrm{Kg}^{-1}$ ) and water (ng $\mathrm{L}^{-1}$ ), respectively.

For calculating $C_{\mathrm{s}}$ concentration of each target compound, Eq. (2.2) was used,

$$
C_{S}=\frac{C_{0}-C_{W}}{S S}
$$

Where, $\mathrm{C}_{0}$ is the measured concentration of each PFC in the water phase at $\mathrm{t}=0$ in flasks with no sludge addition $\left(\mathrm{ng} \mathrm{L}^{-1}\right)$ and $\mathrm{SS}$ is the concentration of sludge suspension used $\left(\mathrm{Kg} \mathrm{L}^{-1}\right)$.

The organic carbon distribution coefficient, $\mathrm{K}_{\mathrm{OC}}\left(\mathrm{L} \mathrm{Kg}_{\mathrm{OC}}{ }^{-1}\right)$ was calculated using the obtained $\mathrm{K}_{\mathrm{d}}$ values, according to Eq. (2.3),

$$
K_{O C}=\frac{K_{d}}{f_{O C}}
$$

Where, $\mathrm{f}_{\mathrm{oc}}$ is the fraction of organic carbon on the sludge (Kg-OC Kg-sludge $\left.{ }^{-1}\right)$.

The fraction $\left(f_{s}\right)$ of each target compound that would be sorbed at equilibrium for a given sludge concentration [Suspended Solids; SS $\left(\mathrm{Kg} \mathrm{L}^{-1}\right)$ ] is given using the experimental $\mathrm{K}_{\mathrm{d}}$ values, according to Andersen et al. (2005), 


$$
f_{S}=\frac{S S \times K_{d}}{1+\left(S S \times K_{d}\right)}
$$

The fraction $\left(\mathrm{F}_{\mathrm{R}}\right)$ of each PFC load that will be removed at equilibrium conditions due to sorption to sludge in primary settling tank $\left(\mathrm{F}_{\mathrm{R}-\mathrm{PS}}\right)$, secondary settling tank $\left(\mathrm{F}_{\mathrm{R}-\mathrm{SS}}\right)$ and anaerobic digester $\left(\mathrm{F}_{\mathrm{R}-}\right.$ DS) can be estimated as shown in Eq. (2.5) [Andersen et al., 2005],

$$
F_{R}=\frac{R E S S \times K_{d}}{1+\left(R E S S \times K_{d}\right)}
$$

Where RESS is the mass of sludge removed per volume of treated sewage $\left(\mathrm{Kg} \mathrm{L}^{-1}\right)$ from each stage of STP.

For RESS calculation at each point of STP, Eq. (2.6) was used [Ternes and Joss, 2006],

$$
R E S S=\frac{\left[\left(Q-Q_{e x}\right) \times X_{S S, \text { out }}\right]+\left(Q_{e x} \times X_{S S, \text { ex }}\right)}{Q}
$$

Where, $Q$ and $Q_{e x}$ are flow rate of treated wastewater and removed sludge $\left(\mathrm{m}^{3} \mathrm{~d}^{-1}\right)$, respectively, while $\mathrm{X}_{\mathrm{SS} \text {,out }}$ and $\mathrm{X}_{\mathrm{SS} \text {,ex }}$ are $\mathrm{SS}$ concentrations in effluent and removed sludge $\left(\mathrm{KgSS} \mathrm{m}^{-3}\right)$, respectively.

As the investigated PFCs are believed not to undergo transformations processes during wastewater treatment, the remaining fraction of PFCs in treated wastewater $\left(\mathrm{F}_{\mathrm{EFF}}\right)$ is determined only by the sorbed amounts over the treatments and can be calculated according to:

$$
F_{E F F}=\left(1-F_{R-P S}\right) \times\left(1-F_{R}-S S\right) \times 100
$$

For cases that a single stage anaerobic digester is followed by dewatering process during sludge treatment, the remaining fraction of target compounds in sludge leachates $\left(\mathrm{F}_{\mathrm{LEAC}}\right)$ can be calculated according to:

$$
F_{L E A C}=\left[\left(F_{R-P S}+F_{R-S S}\right)-F_{R-D S}\right] \times 100
$$

The software GraphPad Prism 5 for Windows was used for data evaluation. The significance of the differences between sorption results was checked by Student t-test at a significance level of 0.05 .

\section{Results and discussion}

\subsection{Sorption of PFCs on different types of sludge}

Removal kinetics of PFCs onto secondary sludge was studied in batch experiments and the ratio between measured aqueous concentration and total initial concentration was calculated at all sampling points (Fig. 1). According to the results, sorption equilibrium was achieved after approximately $4 \mathrm{~h}$ for all PFCs, excepting PFOA for which the equilibrium time was estimated to be $8 \mathrm{~h}$. To ensure that equilibrium had been reached for all PFCs, an equilibrium time of $15 \mathrm{~h}$ was selected for the following sorption experiments. For all PFCs, the mass balance was approximated by comparing the masses on the dissolved and particulate phase to the spiked analyte quantity. Based on these results and on the results from the Control flask (Table S3), neither degradation of target compounds nor adsorption on the flasks were observed (Fig. S1,S2). 


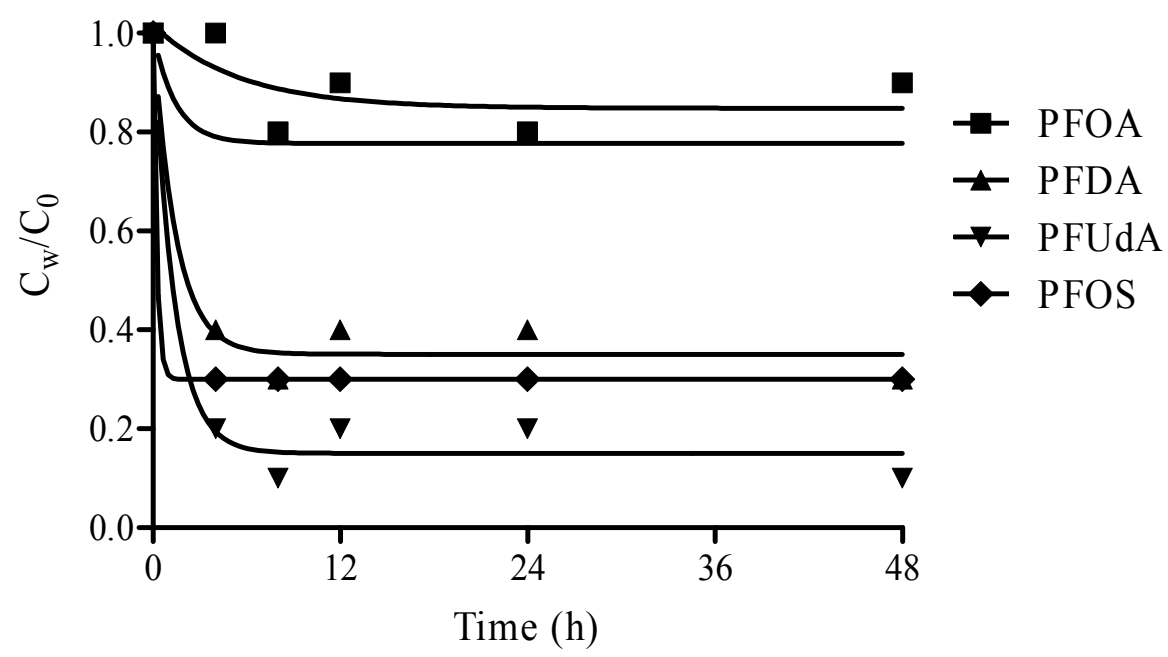

Figure 1: Equilibrium kinetic for sorption of each PFC to secondary sludge at $1.0 \mathrm{~g} \mathrm{~L}^{-1}$. Nominal concentration of each PFC (CO) was $5 \bullet \mathrm{g} \mathrm{L}^{-1}$.

The results clearly distributed evenly in a linear plot of measured $\mathrm{C}_{\mathrm{w}}$ against $\mathrm{C}_{\mathrm{s}}$ calculated with equation 2.2 and therefore no isotherm fittings were attempted and the $\mathrm{K}_{\mathrm{d}}$ values were calculated as the average of all the $K_{d}$ determined by each individual experiment $(n=18)$. The $K_{d}$ values estimated for PFCs ranged from 330 to 6015,329 to 17432 and 162 to $11770 \mathrm{~L} \mathrm{Kg}^{-1}$ for primary, secondary and digested sludge, respectively (Table 1 ). In general, these $\mathrm{K}_{\mathrm{d}}$ values were similar to those reported in previous studies [Yu et al., 2009, Zhou et al., 2010, Arvaniti et al., 2012]. Possible reasons for the deviations observed in some cases could be the different experimental protocol used in each study for $\mathrm{K}_{\mathrm{d}}$ calculation (batch experiments versus full-scale monitoring data), the chemical characteristics of sludge used ( $\mathrm{pH}$, organic carbon, cations) and the different analytical parameters of applied methods. Published $\mathrm{K}_{d}$ values describing PFOA and PFOS sorption onto soils and sediments [Zareitalabad et al., 2013], showed that less part of these compounds is expected to be sorbed on these matrices comparing to sludge.

The sorption capacity of perfluorocarboxylic acids (PFCAs) increased with the increase of the perfluorocarbon chain length (Table 1), due to the hydrophobic and oleophilic character of CarbonFluor chain. PFOS had higher sorption capacity than PFOA due to the presence of one more carbon in the chain and the existence of different functional group with higher acidity (sulfonic acid instead of carboxylic acid) on its molecule. Similar results for the sorption affinity of different PFCs have also been reported in the literature for sludge and sediment [Higgins et al., 2006, Arvaniti et al., 2012, Zhang et al., 2013]. Regarding the effect of sludge used on PFCs' sorption, the application of pairwise $t$-test showed significantly different $K_{d}$ values between primary and secondary sludge for PFDA, PFUdA and PFOS, as well as between primary and digested sludge for PFUdA and PFOS (Table 1). A difference is inspected as the solid matter in the different sludge types has different origin and therefore different qualities in terms of functional groups and polarity.

Using the experimental $\mathrm{f}_{\mathrm{oc}}$ and $\mathrm{K}_{\mathrm{d}}$ values for all target compounds, $\mathrm{K}_{\mathrm{OC}}$ were calculated for different types of sludge (Table 1). According to the results, $\mathrm{K}_{\mathrm{OC}}$ values ranged from 707 to 12853 for the primary sludge, 913 to 48421 for secondary sludge and from 470 to $34116 \mathrm{~L} \mathrm{Kg}_{\mathrm{OC}}{ }^{-1}$ for digested sludge. So far, there is only one study reporting $\mathrm{K}_{\mathrm{OC}}$ values of selected PFCs in sludge. Specifically $\mathrm{Yu}$ et al. (2009) reported lower $\mathrm{K}_{\mathrm{OC}}$ values for PFOA and PFOS in secondary sludge (Table 1). In that study, fraction of organic carbon $\left(f_{o c}\right)$ in secondary sludge was much higher $(0.75)$ comparing to the current study (0.36). 


\subsection{Effect of solution's $p H$}

Calculation of $\mathrm{K}_{\mathrm{d}}$ value for secondary sludge at different $\mathrm{pH}$ showed that PFCs sorption decreased as the solution $\mathrm{pH}$ increased from 6 to 8 (Fig. 2a). By employing pairwise t-test at 95\% confidence level, the difference in the variation of $\mathrm{pH}$ was determined and identified. According to the results, $\mathrm{K}_{\mathrm{d}}$ values were significantly different between $\mathrm{pH} 6$ and 7 as well as between $\mathrm{pH} 6$ and 8. Similar results for the role of $\mathrm{pH}$ on PFCs sorption have been reported by Zhou et al. (2010) and Zhang et al. (2013). Due to extreme pKa values of PFCAs $(<3.13)$ and PFOS (3.27), target compounds exist as anions in the examined $\mathrm{pH}$ range. The overall charge of sludge is positive at lower $\mathrm{pH}$, a fact which increases the concentration of cationic groups that are available for ionic interaction with negative charged PFCs. Additionally at lower $\mathrm{pH}$, the electrostatic repulsion decreases as overall charge on the sludge becomes positive.

\subsection{Effect of ionic strength on sorption}

In the present study, PFCs sorption was affected to different extent by the existence of $\mathrm{Ca}^{2+}$ and $\mathrm{Na}^{+}$(Fig.2b,c). Statistically higher $\mathrm{K}_{d}$ values (pairwise t-test, $\mathrm{p}<0.05$ ) were calculated for all target compounds when the concentration of $\mathrm{Ca}^{2+}$ increased from 1 to $100 \mathrm{mM}$. On the other hand, a lower effect of $\mathrm{Na}^{+}$on PFCs sorption was observed for the same ionic strength and statistically significant differences were found only for PFDA and PFUdA (Fig. 2c). These findings are in agreement with previous reports, which investigated the effect of different cations on the sorption of PFCs to secondary sludge, clay and sediment [Higgins et al., 2006, Zhang et al., 2013]. The positive effect of cations on PFCs sorption could be due to the fact that they act as ion bridges between negatively charged PFCs and sludge. Regarding the different PFCs sorption in presence of $\mathrm{Ca}^{2+}$ and $\mathrm{Na}^{+}$, in a previous study Higgins et al. (2006) reported that these changes in sorption are not simply ionic strength effects and cannot be explained by simple compression of the electrostatic double layer. It is possible that the effects of $\mathrm{Ca}^{2+}$ on sorption are due to a reduction in the charge of organic matter.

\subsection{Assessment of the sorbed fraction of PFCs in the STP}

Typical concentrations of SS in raw wastewater, activated sludge reactor and anaerobic digester were selected and the sorbed fractions of each PFC were predicted for different compartments of a typical STP using Eq. (2.4) (Table 2). Regarding primary sludge, the predicted sorbed fractions were strongly dependent on target compounds, ranging from $3 \%$ for PFOA (SS concentration: $0.1 \mathrm{~g}$ $\mathrm{L}^{-1}$ ) to $55 \%$ for PFUdA (SS concentration: $0.2 \mathrm{~g} \mathrm{~L}^{-1}$ ). These results are consistent with previous experimental data, reporting PFCs distribution in raw wastewater (Arvaniti et al., 2012). In activated sludge and anaerobic digested sludge, due to the elevated SS concentrations in bioreactors, the major part ( $>87 \%)$ of PFDA, PFUdA and PFOS is expected to be sorbed on suspended solids. On the other hand, PFOA that presented the lowest $\mathrm{K}_{d}$ values between target compounds (Table 1) seem to be affected to a greater extent by the concentration of available SS (Table 2). 
Table 1. Average $K_{d}$ and $K_{O C}$ values for PFCs in each sludge and comparison with literature data. The $95 \%$ confidence intervals of measured $K_{d}$ values are given in parenthesis.

\begin{tabular}{|c|c|c|c|c|c|c|c|c|c|}
\hline \multirow{3}{*}{$\begin{array}{l}\text { Target } \\
\text { Analytes }\end{array}$} & \multicolumn{6}{|c|}{ Estimations of this paper } & \multicolumn{3}{|c|}{ Literature data } \\
\hline & \multicolumn{3}{|l|}{$\mathrm{K}_{\mathrm{d}}\left(\mathrm{L} \mathrm{Kg}^{-1}\right)$} & \multicolumn{3}{|c|}{$\mathrm{K}_{\mathrm{OC}}\left(\mathrm{L} \mathrm{Kg}_{\mathrm{OC}}{ }^{-1}\right)$} & \multicolumn{2}{|c|}{$\mathrm{K}_{\mathrm{d}, \mathrm{LIT}}\left(\mathrm{L} \mathrm{Kg}^{-1}\right)$} & \multirow{2}{*}{$\begin{array}{l}\mathrm{K}_{\mathrm{OC}, \mathrm{LIT}} \\
\left(\mathrm{L} \mathrm{Kg}_{\mathrm{OC}}{ }^{-1}\right)\end{array}$} \\
\hline & $\begin{array}{l}\text { Primary } \\
\text { Sludge }\end{array}$ & $\begin{array}{l}\text { Secondary } \\
\text { sludge }\end{array}$ & $\begin{array}{l}\text { Digested } \\
\text { sludge }\end{array}$ & $\begin{array}{l}\text { Primary } \\
\text { sludge }\end{array}$ & $\begin{array}{l}\text { Secondary } \\
\text { sludge }\end{array}$ & $\begin{array}{l}\text { Digested } \\
\text { sludge }\end{array}$ & $\begin{array}{l}\text { Primary } \\
\text { sludge }\end{array}$ & $\begin{array}{l}\text { Secondary } \\
\text { sludge }\end{array}$ & \\
\hline PFOA & $330( \pm 220)$ & $329( \pm 127)$ & $162( \pm 42)$ & $707( \pm 471)$ & $913( \pm 352)$ & $470( \pm 121)$ & $\begin{array}{l}188-597^{\mathrm{a}} \\
212-2657^{\mathrm{b}}\end{array}$ & $\begin{array}{l}201-513^{\mathrm{a}}, 220- \\
870^{\mathrm{b}}, 150-350^{\mathrm{c}}\end{array}$ & $\begin{array}{l}269-676^{\mathrm{a}}, 115^{\mathrm{d}} \\
12-148^{\mathrm{e}}\end{array}$ \\
\hline PFDA & $1601( \pm 477)^{*}$ & $3454( \pm 1185)$ & $2589( \pm 787)$ & $3420( \pm 1019)$ & $9594( \pm 3291)$ & $7506( \pm 2281)$ & $6795-18398^{b}$ & $3637-4830^{b}$ & $575^{\mathrm{d}}$ \\
\hline PFUdA & $6015( \pm 2193)^{*, * *}$ & $17432( \pm 6759)$ & $11770( \pm 3772)$ & $12853( \pm 4686)$ & $48421( \pm 18773)$ & $34116( \pm 10934)$ & $4168-11709^{b}$ & $2281-2660^{b}$ & $1995^{\mathrm{d}}$ \\
\hline PFOS & $1289( \pm 229)^{*, * *}$ & $2226( \pm 392)$ & $1693( \pm 357)$ & $2754( \pm 488)$ & $6184( \pm 1090)$ & $4908( \pm 1035)$ & $\begin{array}{l}894-2237^{\mathrm{a}} \\
398-948^{\mathrm{b}}\end{array}$ & $\begin{array}{l}720-2324^{\mathrm{a}}, 2465- \\
7258^{\mathrm{b}}, 200-4050^{\mathrm{c}}\end{array}$ & $\begin{array}{l}955-3090^{\mathrm{a}}, 372^{\mathrm{d}}, \\
372-1259^{\mathrm{f}}\end{array}$ \\
\hline
\end{tabular}

${ }^{*}$ Statistically significant different $\mathrm{K}_{\mathrm{d}}$ values between primary and secondary sludge (using t-test, $\mathrm{p}<0.05$ )

${ }^{* *}$ Statistically significant different $\mathrm{K}_{\mathrm{d}}$ values between primary and digested sludge (using t-test, $\mathrm{p}<0.05$ ).

${ }^{\mathrm{a}} \mathrm{Yu}$ et al., 2009

${ }^{\mathrm{b}}$ Arvaniti et al., 2012

'Zhou et al., 2010

${ }^{\mathrm{d}}$ Higgins et al., 2006 (experiments with sediment)

${ }^{\mathrm{e}}$ DuPont, 2003 cited in Yu et al. 2009 (experiments with soil)

f 3 , 2000 cited in Yu et al. 2009 (experiments with soil)

Table 2. Estimated fraction of PFCs that is sorbed to primary settling tank, activated sludge tank and anaerobic digester for low and high SS concentrations found in typical STPs.

\begin{tabular}{|c|c|c|c|c|c|}
\hline & $\begin{array}{c}\mathrm{SS} \\
\left(\mathrm{g} \mathrm{L}^{-1}\right)\end{array}$ & $\begin{array}{c}\text { PFOA } \\
(\%)\end{array}$ & $\begin{array}{c}\text { PFDA } \\
(\%)\end{array}$ & $\begin{array}{c}\text { PFUdA } \\
(\%)\end{array}$ & $\begin{array}{c}\text { PFOS } \\
(\%)\end{array}$ \\
\hline Percentage of PFCs sorbed in primary sludge tank $\left(f_{p}\right)$ at low SS & 0.1 & 3 & 14 & 38 & 11 \\
\hline Percentage of PFCs sorbed in primary sludge tank $\left(f_{p}\right)$ at high SS & 0.2 & 6 & 24 & 55 & 20 \\
\hline Percentage of PFCs sorbed in activated sludge tank $\left(\mathrm{f}_{\mathrm{s}}\right)$ at low SS & 3 & 50 & 91 & 98 & 87 \\
\hline Percentage of PFCs sorbed in activated sludge tank $\left(\mathrm{f}_{\mathrm{s}}\right)$ at high SS & 5 & 62 & 95 & 99 & 92 \\
\hline Percentage of PFCs sorbed in anaerobic digester $\left(\mathrm{f}_{\mathrm{d}}\right)$ at low SS & 20 & 76 & 98 & 100 & 97 \\
\hline Percentage of PFCs sorbed in anaerobic digester $\left(f_{d}\right)$ at high SS & 40 & 87 & 99 & 100 & 99 \\
\hline
\end{tabular}



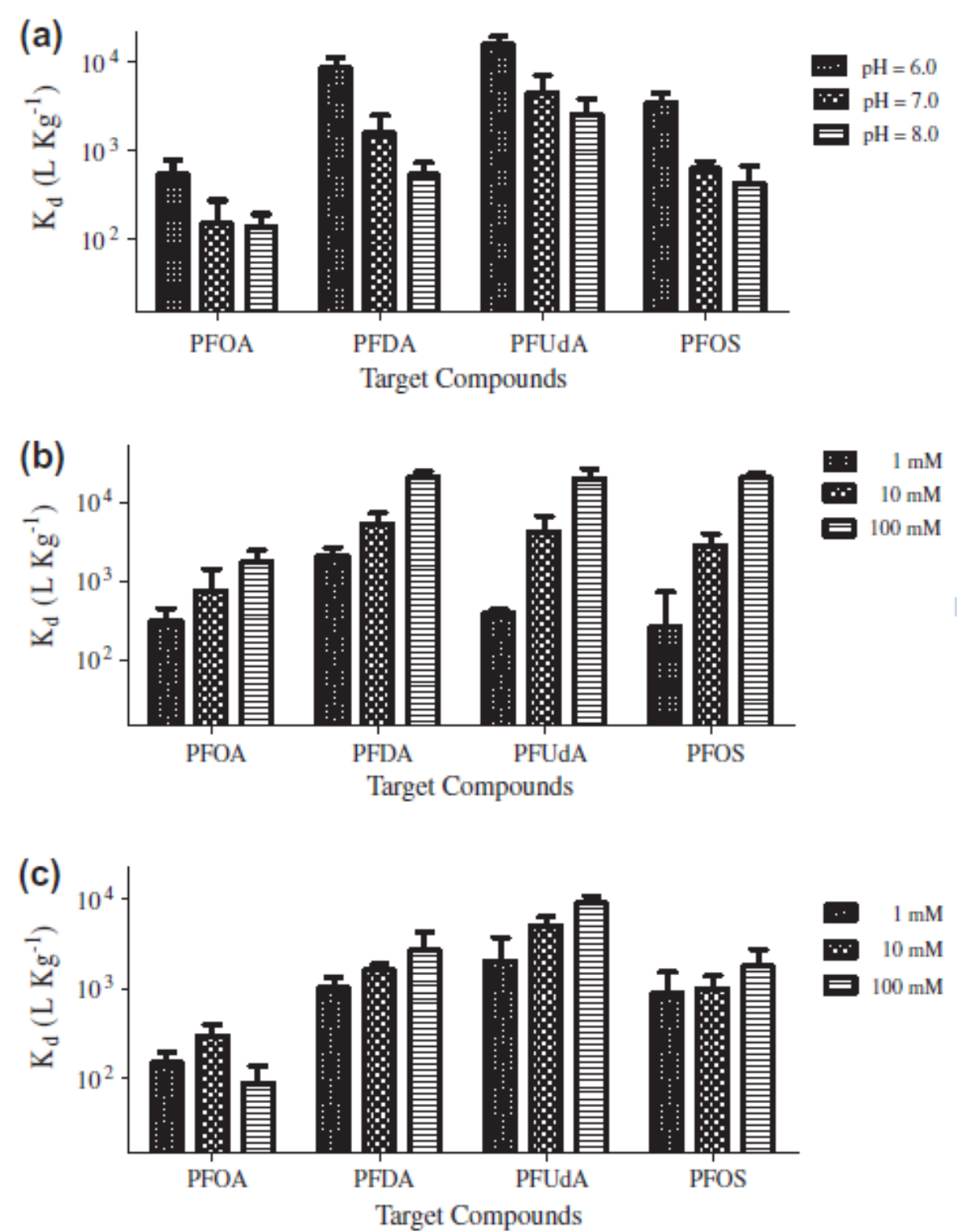

Figure 2: Effect of a) pH, b) $\mathrm{Ca}^{2+}$ and $\mathrm{c}$ ) $\mathrm{Na}^{+}$on PFCs sorption to secondary

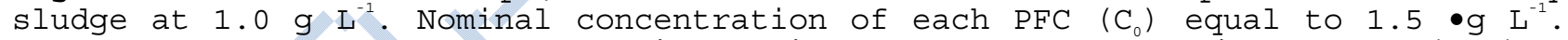
Error bars represent the 95\% confidence interval for each examined value ( $\mathrm{n}=3$ ).

\subsection{Assessment of PFCs removal in the STP}

In a conventional STP, typical values for the removal of primary and secondary sludge per volume of treated sewage are $210 \mathrm{~g} \mathrm{~m}^{-3}$ [Hörsing et al., 2011] and $250 \mathrm{~g} \mathrm{~m}^{-3}$ [Ternes and Joss, 2006], respectively. Since the investigated PFCs are neither volatile nor degraded in a STP, applying these values and the experimental $\mathrm{K}_{\mathrm{d}}$, the loss of PFCs due to sorption in primary and secondary settling tank and the load discharged via treated wastewater to the environment can be estimated with Eq.(2.5)-(2.7).

As shown in Fig. 3 and Table S7, except for PFOA of which $86 \%$ of the initial load is expected to be discharged into the environment via treated wastewater, all other target compounds is predicted to be significantly removed ( $>49 \%$ of initial loading) by sorption to primary and secondary excess sludge. Taking into account that PFCAs with C5 to C14 are usually detected in raw wastewater, the results presented in paragraphs 3.1 and 3.5 indicate that PFCAs with less than 10 carbon atoms are expected to be detected mainly in treated wastewater. According to Eq. (2.5)-(2.7), the critical $\mathrm{K}_{\mathrm{d}}$ 
values for achieving high (> 60\%) PFCs' removal via sludge is $2500 \mathrm{~L} \mathrm{Kg}^{-1}$. Contrary to the aforementioned estimations, previously published monitoring studies have reported negative removals in a STP, especially for PFOS and PFOA (Sinclair and Kannan, 2006, Arvaniti et al., 2012). These observations are due to the significant formation of PFCs by precursors found in domestic wastewater (e.g. fluorotelomers); a mechanism which was not quantified in the current study. The results of this study indicate the ability of sludge to remove significant part of PFCs and for the first time assess systematically the role of sorption on their fate during wastewater treatment. Further research should be performed in order to quantify PFCs' formation in STPs.

Prediction of PFCs' removal with secondary excess sludge within $\mathrm{pH}$ values and cations concentrations checked in this study showed that commonly observed fluctuations of these parameters can affect PFCs behavior in a STP (Table S8). For instance, a decrease of $\mathrm{pH}$ from 7 to 6 would increase target compounds' removal about 1.5 (PFUdA) to 3.5 (PFOS) fold, while increase of $\left[\mathrm{Ca}^{2+}\right]$ from 1 to $10 \mathrm{mM}$ would multiply PFCs' removal depending on the compound.

For the cases that anaerobic digester is followed by dewatering process, by use of Eq. $(2.5,2.6$ and 2.8), the fractions of each PFC load that would be removed due to sorption to sludge and discharged via leachates were estimated (Fig. 3). Since the SS concentrations in anaerobic digester are high, the major part of incoming PFCs in digester is expected to be removed via treated sludge. However, for the less hydrophobic compounds (e.g. PFOA), a small but not negligible amount of initial load $(\approx 3 \%)$ seems to end up in leachates and transferred to the inlet of STP.

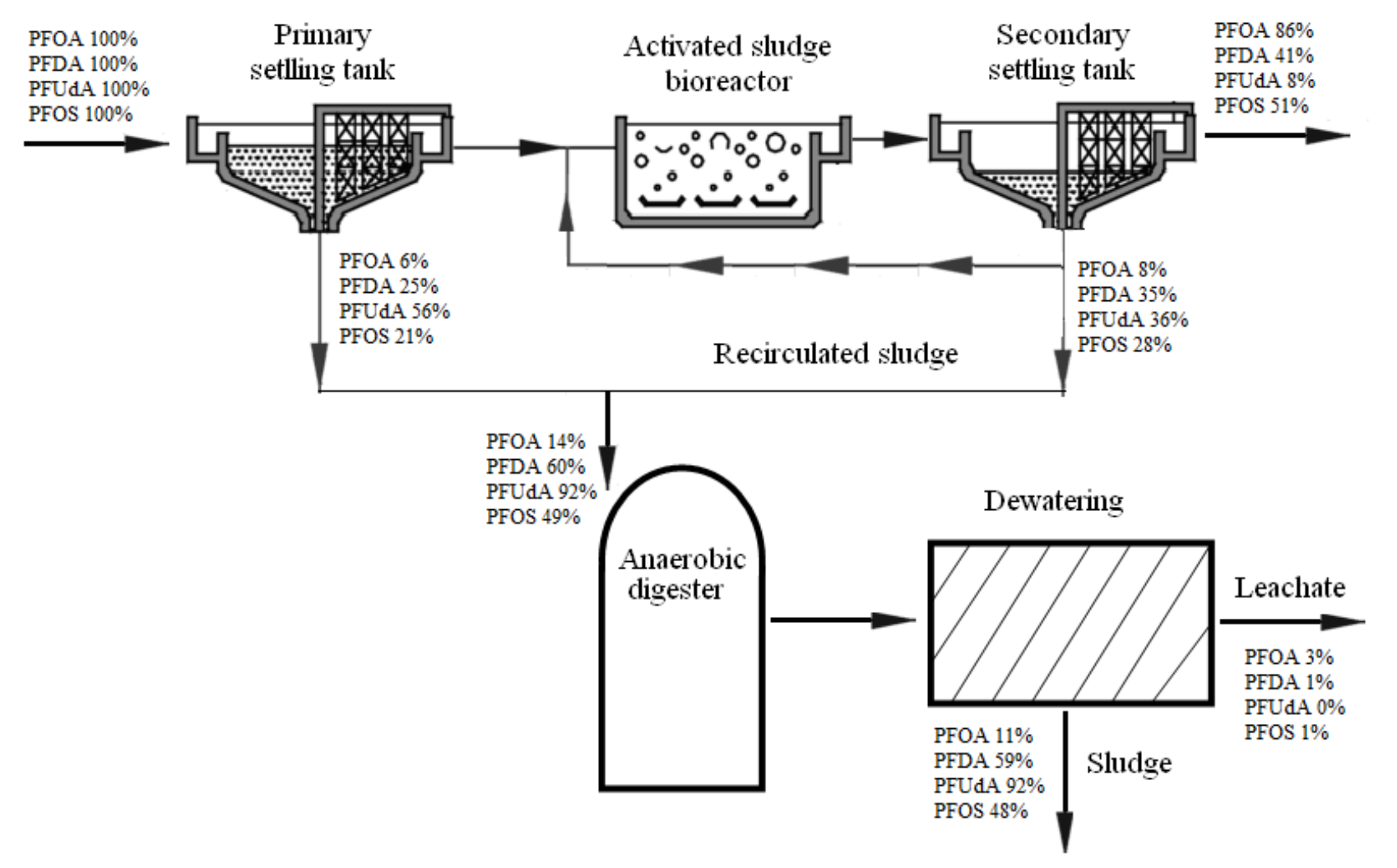

Figure 3. The predicted fate of examined PFCs in a typical STP, based on the experimentally determined sorption constants and production of primary and secondary sludge. 


\section{Conclusion}

$\mathrm{K}_{\mathrm{d}}$ values of selected PFCs in primary, secondary and digested sludge were calculated in batch experiments. Longer PFCAs and PFOS exhibited high $\mathrm{K}_{d}$ values, indicating that PFCs' sorption on sludge occurs due to hydrophobic interactions. Assuming that PFCs are neither volatile nor degraded in STP and target compounds' formation due to precursors is negligible, $\mathrm{K}_{\mathrm{d}}$ values were used to evaluate the fate of PFCs in a typical STP. According to the results, PFCs with short chain length are expected to be detected mainly in treated wastewater, while longer compounds will be removed via sludge disposal. Variations in $\mathrm{pH}$ values and $\left[\mathrm{Ca}^{2+}\right],\left[\mathrm{Na}^{+}\right]$during wastewater treatment can significantly affect fate and removal of PFCs in a STP.

\section{Acknowledgments}

This project was implemented under the Operational Program "Education and Lifelong Learning" and funded by the European Union (European Social Fund) and National ResourcesHRAKLEITOS II.

\section{References}

Ahrens, L., 2011. Polyfluoroalkyl compounds in the aquatic environment: a review of their occurrence and fate. J. Environ. Monit. 13, 20-31.

Andersen, H.R., Hansen, M., Kjølholt, J., Stuer-Lauridsen, F., Ternes, T., Halling-Sørensen, B., 2005. Assessment of the importance of sorption for steroid estrogens removal during activated sludge treatment. Chemosphere 61, 139-146.

Arvaniti, O.S., Ventouri, E.I., Stasinakis, A.S., Thomaidis, N.S., 2012. Occurrence of different classes of perfluorinated compounds in Greek wastewater treatment plants and determination of their solid-water distribution coefficients. J. Hazard. Mater. 239-240, 24-31.

Arvaniti, O.S., Dasenaki, M.E., Ventouri, E.I., Stasinakis, A.S., Thomaidis, N.S, 2014. Simultaneous determination of eighteen perfluorinated compounds in dissolved and particulate phases of wastewater, and in sewage sludge by liquid chromatography-tandem mass spectrometry. Anal. Methods 6, 1341-1349.

Eschauzier, C., Raat, K.J., Stuyfzand, P.J., Voogt, P., 2013. Perfluorinated alkylated acids in groundwater and drinking water: Identification, origin and mobility. Sci. Total Environ. 458-460, 477-485.

Higgins, C.P., Luthy, R.G., 2006. Sorption of perfluorinated surfactants on sediments. Environ. Sci. Technol. 40, 7251-7256.

Hörsing, M., Ledin, A., Grabic, R., Fick, J., Tysklind, M., Jansen, J.L.C., Andersen, H.R., 2011. Determination of sorption of seventy-five pharmaceuticals in sewage sludge. Water Res. 45, 4470-4482.

Müller, C.E., Gerecke, A.C., Alder, A.C., Scheringer, M., Hungerbühler, K., 2011. Indentification of perfluoroalkyl acid sources in Swiss surface with the help of the artificial sweetener acesulfate. Environ. Pollut. 159, 1419-1426.

Ochoa-Herrera, V., Sierra-Alvarez, R., 2008. Removal of perfluorinated surfactants by sorption onto granular activated carbon, zeolite and sludge. Chemosphere 72, 1588-1593.

Pico, Y., Blasco, C., Farré, M., Barceló, D., 2012. Occurrence of perfluorinated compounds in water and sediment of L'Albufera Natural Park (València, Spain). Environ. Sci. Pollut. Res. 19, 946-957.

Pierre, H., Maud, V., Benoit, M., 2013. Determination of sorption properties of micropollutants: what is the most suitable activated sludge inhibition technique to preserve the biomass structure? Chem. Eng. J. 242, 260-268.

Sinclair, E., Kannan, K., 2006. Mass loading and fate of perfluoroalkyl surfactants in wastewater treatment plants. Environ. Sci. Technol. 40, 1408-1414. 
Stasinakis, A.S., Thomaidis, N.S., Arvaniti, O.S., Asimakopoulos, A.G., Samaras, V.G., Ajibola, A., Mamais, D., Lekkas, T.D., 2013. Contribution of primary and secondary treatment on the removal of benzothiazoles, benzotriazoles, endocrine disruptors, pharmaceuticals and perfluorinated compounds in a sewage treatment plant. Sci. Total Environ. 463-464, 1067-1075.

Ternes, A.T., Joss, A. 2006. Human Pharmaceutical, Hormones and Fragrances, first ed. London, UK.

Wang, P., Wang, T., Giesy, J.P., Lu, Y., 2013. Perfluorinated compounds in soils from Liaodong Bay with concentrated fluorine industry parks in China. Chemosphere 91, 751-757.

Wick, A., Marincas, O., Moldovan, Z., Ternes, T.A, 2011. Sorption of biocides, triazine and phenylurea herbicides, and UV-filters onto secondary sludge. Water Res. 45, 3638-3652.

Yu, J., Hu, J., Tanaka, S., Fujii, S., 2009. Perfluorooctanesulfonate (PFOS) and perfluorooctanoic acid (PFOA) in sewage treatment plants. Water Res. 43, 2399-2408.

Zareitalabad, P., Siemens, J., Hamer, M., Amelung, W., 2013. Perfluorooctanoic acid (PFOA) and perfluorooctanesulfonic acid (PFOS) in surface waters, sediments, soils and wastewater - A review on concentrations and distribution coefficients. Chemosphere 91, 725-732.

Zhang, C., Yan, H., Li, F., Hu, X., Zhou, Q., 2013. Sorption of short- and long-chain perfluoroalkyl surfactants on sewage sludges. J. Hazard. Mater. 260, 689-699.

Zhou, Q., Deng, S., Zhang, Q., Fan, Q., Huang, J., Yu,G., 2010. Sorption of perfluorooctanesulfonate and perfluorooctanoate on activated sludge. Chemosphere 81, 453-458. 


\section{Appendix A: Supplementary material}

Table s1. Target compounds and internal standards that were used in the present study.

\begin{tabular}{|c|c|c|c|c|}
\hline Compounds & Molecular structure & $\begin{array}{l}\text { Molecular } \\
\text { Weight }\end{array}$ & $\operatorname{LogK}_{\text {ow }}$ & $\mathrm{pKa}$ \\
\hline \multicolumn{5}{|c|}{ Target compounds } \\
\hline Perfluorooctanoic acid (PFOA) & $\mathrm{CF}_{3}\left(\mathrm{CF}_{2}\right)_{6} \mathrm{COOH}$ & 414.07 & $3.60^{1}$ & $2.5^{2}$ \\
\hline Perfluorodecanoic acid (PFDA) & $\mathrm{CF}_{3}\left(\mathrm{CF}_{2}\right)_{8} \mathrm{COOH}$ & 514.09 & $5.40^{1}$ & $2.606^{3}$ \\
\hline Perfluoroundecanoic acid(PFUdA) & $\mathrm{CF}_{3}\left(\mathrm{CF}_{2}\right)_{9} \mathrm{COOH}$ & 564.09 & $5.76^{4}$ & $3.128^{3}$ \\
\hline Perfluorooctanesulfonate (PFOS) & $\mathrm{CF}_{3}\left(\mathrm{CF}_{2}\right)_{7} \mathrm{SO}_{3} \mathrm{Na}$ & 522.11 & $4.30^{1}$ & $3.27^{5}$ \\
\hline \multicolumn{5}{|c|}{ Internal standards } \\
\hline $\begin{array}{l}\text { Perfluoro-n- }\left[1,2,3,4-{ }^{13} \mathrm{C}_{4}\right] \text { octanoic } \\
\text { acid (MPFOA) }\end{array}$ & $\mathrm{CF}_{3}\left(\mathrm{CF}_{2}\right)_{3}\left({ }^{13} \mathrm{CF}_{2}\right)_{3}{ }^{13} \mathrm{COOH}$ & 418.04 & $3.60^{1}$ & $2.5^{2}$ \\
\hline $\begin{array}{l}\text { Sodium perfluoro-1- }[1,2,3,4- \\
\left.{ }^{13} \mathrm{C}_{4}\right] \text { octanesulfonate (MPFOS) }\end{array}$ & $\mathrm{CF}_{3}\left(\mathrm{CF}_{2}\right)_{3}\left({ }^{13} \mathrm{CF}_{2}\right)_{4} \mathrm{SO}_{3} \mathrm{Na}$ & 526.08 & $4 \cdot 30^{1}$ & $3.27^{5}$ \\
\hline
\end{tabular}

${ }^{1}$ Kelly, B.C., Iconomou, M.G., Blair, J.D., Surridge, B., Hoover, D., Grace, R., Gobas,

F.A.P.C.,2009. Perfluoroalkyl contaminants in an arctic marine food web: Trophic magnification and wildlife exposure, Environ. Sci. Technol. 43,4037-4043.

${ }^{2}$ USEPA, 2002. Revised Draft Hazard Assessment of Perfluorooctanoic Acid and its Salts Available

from: http://www.ewg.org/files/EPA_PFOA_110402.pdf.

Moroi, Y., Yano, H., Shibata, O., Yonemitsu, T., 2001. Determination of Acidity Constants of

Perfluoroalkanoic Acids., Bull. Chem. Soc. Jpn. 74, 667-672.

${ }^{4}$ Arp, H.P.H., Niederer, C., Goss, K., 2006. Predicting the partitioning behavior of various highly

fluorinated compounds. Environ. Sci. Technol. 40, 7298-7304.

${ }^{5}$ Brooke, D., Footitt, A., Nwaogu, T.A., 2004 . Environmental Risk Evaluation Report:

PerfluorooctaneSulfonate (PFOS), UK Environment Agency.

Table s2. Characteristics of sludge collected from Athens STP ( $\mathrm{n}=2$ ). These

values were measured before sludge preparation for sorption experiments (washing, 
freeze drying and sterilizing).

\begin{tabular}{|c|c|c|c|}
\hline \multirow[t]{2}{*}{ Parameters } & \multicolumn{3}{|c|}{ Type of sludge } \\
\hline & $\begin{array}{l}\text { Primary } \\
\text { sludge }\end{array}$ & $\begin{array}{l}\text { Secondary } \\
\text { sludge }\end{array}$ & $\begin{array}{l}\text { Digested } \\
\text { sludge }\end{array}$ \\
\hline $\begin{array}{l}\text { Total Suspended Solids } \\
\left(\mathrm{g} \mathrm{L}^{-1}\right)\end{array}$ & 29.3 & 6.0 & 24.9 \\
\hline $\begin{array}{l}\text { Volatile Suspended } \\
\text { Solids }\left(g \mathrm{~L}^{-1}\right)\end{array}$ & 28.3 & 5.2 & 18.3 \\
\hline $\mathrm{pH}$ & 6.48 & 6.54 & 7.46 \\
\hline Conductivity $\left(\mathrm{mS} \mathrm{cm}^{-1}\right)$ & 1.64 & 1.08 & 8.59 \\
\hline Loss On Ignition (\%) & 82.9 & 88.5 & 71.9 \\
\hline $\begin{array}{l}\text { Oxidizable Organic } \\
\text { Carbon (\%) }\end{array}$ & 46.8 & 36.0 & 34.5 \\
\hline $\mathrm{Cl}^{-}(\mathrm{mM})$ & 0.29 & 0.23 & 0.32 \\
\hline $\mathrm{Na}^{+} \quad(\mathrm{mM})$ & 0.58 & 0.57 & 0.67 \\
\hline $\mathrm{Ca}^{2+}(\mathrm{mM})$ & 0.89 & 0.37 & 3.0 \\
\hline $\mathrm{Mg}^{2+}(\mathrm{mM})$ & 0.18 & 0.24 & 0.60 \\
\hline
\end{tabular}


Table s3. Experimental protocol used in PFCs sorption experiments ( $\mathrm{n}=3$ )

\begin{tabular}{|c|c|c|c|c|c|c|c|c|c|c|}
\hline Type & & $\mathrm{PFC}$ & ikec & $\begin{array}{l}-1 \\
-1\end{array}$ & & & $\mathrm{pH}$ & $\begin{array}{l}\mathrm{Na}^{+} \\
(\mathrm{mM})\end{array}$ & $\begin{array}{l}\mathrm{Ca}^{2+} \\
(\mathrm{mM})\end{array}$ & $\begin{array}{c}\text { Sludge } \\
\text { concentration }\end{array}$ \\
\hline $\begin{array}{l}\text { Unspiked } \\
\text { sludge }\end{array}$ & 0 & - & - & - & - & - & - & & - & 1 \\
\hline $\begin{array}{l}\text { Control (no } \\
\text { sludge) }\end{array}$ & 0.2 & 0.4 & 0.8 & 1.5 & 3 & 5 & 8.24 & 0.53 & 0.78 & 0 \\
\hline $\begin{array}{l}\text { Primary } \\
\text { sludge }\end{array}$ & 0.2 & 0.4 & 0.8 & 1.5 & 3 & 5 & 7.02 & 2.7 & 1.7 & 1 \\
\hline \multirow{3}{*}{$\begin{array}{l}\text { Secondary } \\
\text { sludge }\end{array}$} & 0.2 & 0.4 & 0.8 & 1.5 & 3 & 5 & 6.88 & 1.8 & 1.1 & 1 \\
\hline & - & - & - & 1.5 & - & - & $6,7,8$ & 1.8 & 1.1 & 1 \\
\hline & - & - & - & 1.5 & - & - & $\begin{array}{c}7.08^{2}, 6.91^{2} \\
6.79^{2} \\
7.04^{3}, 6.68^{3} \\
6.45^{3}\end{array}$ & $1,10,100$ & $1,10,100$ & 1 \\
\hline $\begin{array}{l}\text { Digested } \\
\text { sludge }\end{array}$ & 0.2 & 0.4 & 0.8 & 1.5 & 3 & 5 & 7.23 & 1.9 & 1.1 & 1 \\
\hline
\end{tabular}

${ }^{1}$ The number of replicates in each sorption experiment is given in parenthesis.

${ }^{2}$ The $\mathrm{pH}$ values when the concentrations of $\mathrm{Na}^{+}$were 1,10 and $100 \mathrm{mM}$, respectively.

${ }^{3}$ The $\mathrm{pH}$ values when the concentrations of $\mathrm{Ca}^{2+}$ were 1,10 and $100 \mathrm{~mm}$, respectively. 
Table S4. Optimized conditions for HPLC-MS analysis.

\begin{tabular}{|c|c|c|c|}
\hline HPLC system & & MS system & \\
\hline Instrument & Agilent-1200 HPLC & Instrument & Agilent 1100 MSD \\
\hline Column & $\begin{array}{l}\text { XTerra MS C18 } \\
(2.1 \mathrm{mmi} . \mathrm{d} . \mathrm{x} 100 \mathrm{~mm}, \\
3.5 \bullet \mathrm{m})\end{array}$ & Interface & $\begin{array}{l}\text { Electrospray } \\
\text { ionization } \\
\text { (negative mode) }\end{array}$ \\
\hline $\begin{array}{l}\text { Guard } \\
\text { column }\end{array}$ & $\begin{array}{l}\text { Luna C18 } \\
(2.0 \mathrm{mmi} . \mathrm{d} . \mathrm{x} 4 \mathrm{~mm}, 5 \bullet \mathrm{m})\end{array}$ & $\begin{array}{l}\text { Capillary } \\
\text { voltage }\end{array}$ & $3500 \mathrm{~V}$ \\
\hline $\begin{array}{l}\text { Injected } \\
\text { volume }\end{array}$ & $10 \bullet L$ & $\begin{array}{l}\text { Capillary } \\
\text { temperature }\end{array}$ & $350{ }^{\circ} \mathrm{C}$ \\
\hline Temperature & $25{ }^{\circ} \mathrm{C}$ & Drying gas & $8 \mathrm{~L} \mathrm{~min}^{-1}$ \\
\hline Flow rate & $100 \cdot \mathrm{L} \mathrm{min}^{-1}$ & Nebulizer gas & $30 \mathrm{psi}$ \\
\hline $\begin{array}{l}\text { Mobile } \\
\text { phase }\end{array}$ & $\begin{array}{l}\text { A) } \mathrm{MeOH} \\
\text { B) } \mathrm{HCOONH}_{4}, \quad 5 \mathrm{mM}\end{array}$ & & \\
\hline $\begin{array}{l}\text { Gradient } \\
\text { program }\end{array}$ & $\begin{array}{l}0 \min 70 \% \mathrm{~A}, 2 \min 85 \% \mathrm{~A} \\
12 \min 100 \% \mathrm{~A}, 18 \mathrm{~min} 100 \% \\
\mathrm{~A}, 18.2-40 \mathrm{~min} 70 \% \mathrm{~A}\end{array}$ & 18 & \\
\hline
\end{tabular}


Table s5. Linearity data, recoveries and methods' LODs and LoQs for the determination of PFCs in wastewater and sludge samples.

\begin{tabular}{|c|c|c|c|c|c|c|c|c|}
\hline \multirow[b]{2}{*}{$\begin{array}{c}\text { Target } \\
\text { Analytes }\end{array}$} & \multirow[b]{2}{*}{$\begin{array}{l}\text { Linear } \\
\text { ity } \\
\text { range } \\
\text { (ng L } \\
1\end{array}$} & \multirow[b]{2}{*}{$\begin{array}{c}\text { Correlati } \\
\text { on } \\
\text { coefficie } \\
\text { nt } \\
\left(r^{2}\right)\end{array}$} & \multicolumn{2}{|c|}{ Wastewater } & \multicolumn{2}{|c|}{ Sewage Sludge } & $\begin{array}{c}\text { Wastewate } \\
r\end{array}$ & \multirow{2}{*}{$\begin{array}{l}\text { Sewage } \\
\text { sludge }\end{array}$} \\
\hline & & & $\begin{array}{c}\text { LOD } \\
\left(\mathrm{ng} \mathrm{L}^{-}\right. \\
\left.{ }^{1}\right) \\
(\mathrm{n}= \\
6)^{1}\end{array}$ & $\begin{array}{l}\text { LOQ } \\
\left(\begin{array}{c}\text { ng L } \\
\left.{ }^{1}\right)\end{array}\right.\end{array}$ & $\begin{array}{c}\text { LOD } \\
\left(\begin{array}{c}\text { ng } 9^{-} \\
1\end{array}\right) \\
(\mathrm{n}= \\
6)^{1}\end{array}$ & $\begin{array}{c}\text { LOQ } \\
\left(\begin{array}{c}\text { ng } \\
\left.{ }^{1}\right)\end{array}\right.\end{array}$ & $\begin{array}{c}\text { Mean recor } \\
(\mathrm{n}\end{array}$ & \\
\hline PFOA & $1-100$ & 0.9980 & 28.5 & 85.5 & 25.0 & 75.0 & $112 \pm 3.3$ & $\begin{array}{c}86.6 \pm \\
5.1\end{array}$ \\
\hline PFDA & $1-100$ & 0.9991 & 31.6 & 94.8 & 14.0 & 42.0 & $\begin{array}{c}96.7 \pm \\
0.88\end{array}$ & $\begin{array}{c}65.8 \pm \\
6.6\end{array}$ \\
\hline PFUdA & $1-100$ & 0.9992 & 15.3 & 45.9 & 8.3 & 25.6 & $\begin{array}{c}72.3 \pm \\
0.15\end{array}$ & $\begin{array}{c}54.6 \pm \\
7.0\end{array}$ \\
\hline PFOS & $1-100$ & 0.9996 & 22.6 & 67.8 & 5.8 & 17.4 & $112 \pm 2.2$ & $\begin{array}{c}93.2 \pm \\
7.4\end{array}$ \\
\hline
\end{tabular}

The number of replicates in validation experiment is given in parenthesis. 


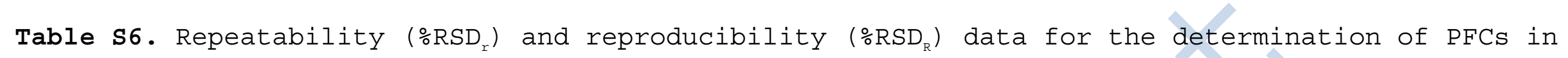
wastewater and sludge samples.

\begin{tabular}{|c|c|c|c|c|c|c|}
\hline \multirow{3}{*}{$\begin{array}{l}\text { Target } \\
\text { Analytes }\end{array}$} & \multicolumn{3}{|c|}{ Wastewater } & \multicolumn{3}{|c|}{ Sewage sludge } \\
\hline & \multicolumn{2}{|c|}{$\frac{\mathrm{RSD}}{\mathrm{r}}$} & $\div \mathrm{RSD}_{\mathrm{R}}$ & $\% \mathrm{RSI}$ & $r$ & $\div \mathrm{RSD}_{\mathrm{R}}$ \\
\hline & $\begin{array}{c}20 \mathrm{ng} \mathrm{L^{-1 }} \\
(\mathrm{n}=6)\end{array}$ & $\begin{array}{c}100 \mathrm{ng} \mathrm{L}^{-1} \\
(\mathrm{n}=4)\end{array}$ & $\begin{array}{c}100 \mathrm{ng} \mathrm{L} \\
(\mathrm{n}=11)\end{array}$ & $\begin{array}{c}20 \mathrm{ng} \mathrm{L^{-1 }} \\
(\mathrm{n}=6)\end{array}$ & $\begin{array}{c}50 \mathrm{ng} \mathrm{L}^{-1} \\
(\mathrm{n}=4)\end{array}$ & $\begin{array}{c}100 \mathrm{ng} \mathrm{L}^{-1} \\
(\mathrm{n}=6)\end{array}$ \\
\hline PFOA & 14 & 2.7 & 7.1 & 16 & 5.1 & 9.6 \\
\hline PFDA & 12 & 9.5 & 11 & 12 & 6.6 & 8.7 \\
\hline PFUdA & 8.6 & 5.0 & 12 & 15 & 7.0 & 14.8 \\
\hline PFOS & 13 & 5.2 & 8.1 & 3.4 & 7.4 & 2.1 \\
\hline
\end{tabular}


Table s7. Fraction of each PFC load that is removed due to sorption to sludge in primary settling tank $\left(F_{R-P S}\right)$, secondary settling tank $\left(F_{R-S S}\right)$ and discharged in effluent wastewater $\left(F_{E F F}\right)$.

\begin{tabular}{|c|c|c|c|c|}
\hline & $\begin{array}{l}\text { PFOA } \\
(\%)\end{array}$ & $\begin{array}{l}\text { PFDA } \\
(\%)\end{array}$ & $\begin{array}{l}\text { PFUdA } \\
(\%)\end{array}$ & $\begin{array}{c}\text { PFOS } \\
(\%)\end{array}$ \\
\hline $\begin{array}{l}\text { Percentage of PFCs load removed with primary sludge } \\
\text { for RESS equal to } 210 \mathrm{~g} \mathrm{~m}^{3} \text {-treated water }\left(\mathrm{F}_{\mathrm{R}-\mathrm{PS}}\right)\end{array}$ & 6 & 25 & 56 & 21 \\
\hline $\begin{array}{l}\text { Percentage of PFCs load removed with secondary } \\
\text { excess sludge for RESS equal to } 250 \mathrm{~g} \mathrm{~m}^{3} \text {-treated } \\
\text { water }\left(\mathrm{F}_{\mathrm{R}-\mathrm{SS}}\right)\end{array}$ & & 46 & 81 & 36 \\
\hline $\begin{array}{l}\text { Percentage of PFCs discharged in effluent } \\
\text { wastewater }\left(F_{\mathrm{EFF}}\right)\end{array}$ & 86 & 41 & 8 & 51 \\
\hline
\end{tabular}


Table s8. Fraction of each PFC load that is removed due to sorption to sludge in secondary settling tank $\left(\mathrm{F}_{\mathrm{R}-\mathrm{SS}}\right)$ at different $\mathrm{pH}$ and concentrations of cations.

\begin{tabular}{|l|c|c|c|c|c|c|c|c|c|}
\hline \multirow{2}{*}{$\begin{array}{c}\text { Target } \\
\text { Analytes }\end{array}$} & \multicolumn{3}{|c|}{$\mathrm{pH}$} & \multicolumn{5}{c|}{$\mathrm{Ca}^{2+}$} & \multicolumn{2}{c|}{$\mathrm{Na}^{+}$} \\
\cline { 2 - 12 } & 6 & 7 & 8 & $1 \mathrm{mM}$ & $10 \mathrm{mM}$ & $100 \mathrm{mM}$ & $1 \mathrm{mM}$ & $10 \mathrm{mM}$ & $100 \mathrm{mM}$ \\
\hline PFOA & $12 \%$ & $4 \%$ & $3 \%$ & $7 \%$ & $15 \%$ & $30 \%$ & $4 \%$ & $7 \%$ & $2 \%$ \\
\hline PFDA & $68 \%$ & $28 \%$ & $12 \%$ & $34 \%$ & $60 \%$ & $84 \%$ & $20 \%$ & $29 \%$ & $40 \%$ \\
\hline PFUdA & $80 \%$ & $53 \%$ & $39 \%$ & $9 \%$ & $51 \%$ & $83 \%$ & $34 \%$ & $55 \%$ & $69 \%$ \\
\hline PFOS & $47 \%$ & $13 \%$ & $10 \%$ & $6 \%$ & $41 \%$ & $84 \%$ & $18 \%$ & $20 \%$ & $31 \%$ \\
\hline
\end{tabular}




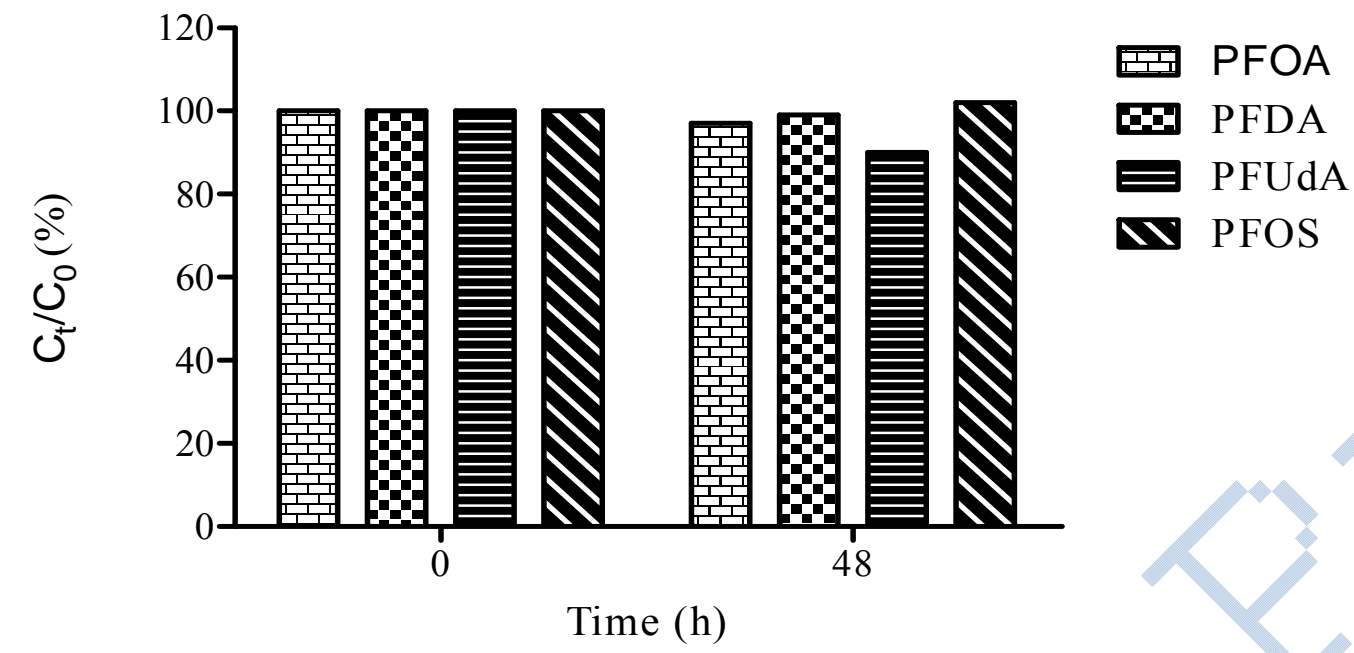

Fig. S1. Ratio (\%) of the total (dissolved + particulate) concentration at time $t$ ( $C_{t}$ ) to the initial concentration $\left(\mathrm{C}_{0}\right)$ (spiked level: $5 \bullet \mathrm{g} \mathrm{L}^{-1}$ for each $\mathrm{PFC}$, no biomass). 


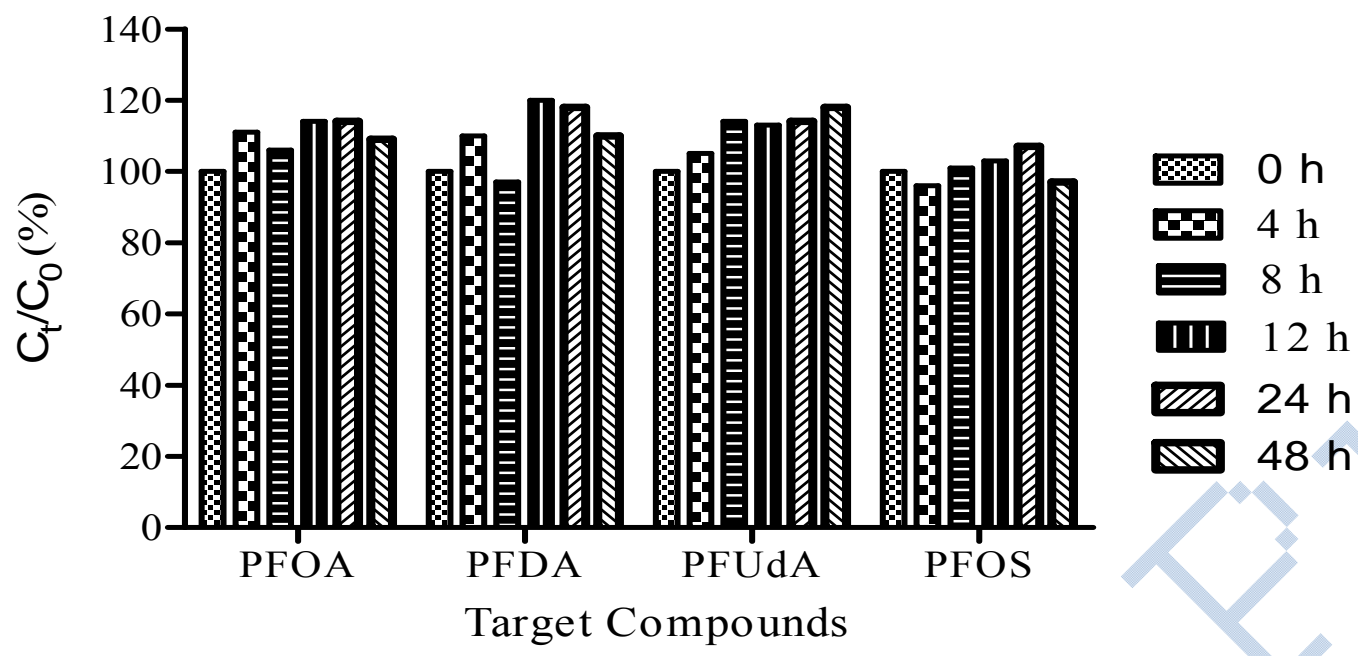

Fig. S2. Ratio (\%) of the total (dissolved + particulate) concentration at time $t$ ( $C_{t}$ ) to the initial concentration $\left(C_{0}\right)$ (spiked level: $5 \bullet \mathrm{g} \mathrm{L}^{-1}$ for each PFC, $1.0 \mathrm{~g} / \mathrm{L}$ sludge). 